\title{
UDC 342.951
}

DOI https://doi.org/10.32840/1813-338X-2019-4-17

\section{D. Pastukh}

$\mathrm{PhD}$ in Law, Associate Professor, Head of the Department of Public Management and Administration of the National Academy of Internal Affairs

\section{CONFLICT OF INTEREST SETTLEMENT IN PUBLIC SERVICE}

The scientific publication on the basis of the current legislation, the achievements of legal science reveals the actual problems of the settlement of conflicts of interest in public-legal relations. It is stated that the current anti-corruption legislation does not fully define the forms and procedures of such conflicts settlement, which depends directly on their specificity, duration, content of the conflict situation, etc. All this leads to difficulties in the settlement of conflicts by authorized entities.

The legislator's approaches to ways of conflicts of interest settlement in public administration activities are disclosed. The procedure and reasons for the use of measures of non-dependent and external conflict of interest settlement are explained. It is noted that the choice of a specific measure for the settlement of an external conflict of interests must be carried out objectively, taking into account the interests of the person who has a conflict, the specificity of their official powers, in order to prevent violations of the rights, freedoms and legitimate interests of individuals and legal entities.

Ways of applying measures of external settlement of conflict of interests are described in detail, taking into account the type of conflict, its duration, the person in conflict, the person authorized to resolve it, and the forms of settlement. In particular, it is noted that such measures as the transfer of a person to another position, as well as his dismissal, shall be applied only by the head of the body, enterprise, institution or organization. The decision on the application of other measures of external regulation may also be taken by the direct supervisor of the person. The decision to remove a person from performing a task, committing an action, taking a decision or participating in its adoption in a real or potential conflict of interest may be taken both verbally and in writing. Decisions on the application of other measures of external settlement are taken in writing.

Attention is paid to the gaps in the relevant legislation, specific proposals for their elimination are determined by legislatively fixing the form of the decision of the head on the resolution of the conflict, requirements for its organizational level.

Key words: conflict of interest, public administration, potential conflict of interest, real conflict of interests, external settlement measures, non-dependent settlement measures.

Introduction. The obligation to take measures to prevent conflicts of interest is the one of many requirements for a person who entering the public service. The legislator puts on the head of the body the responsibility to take a decision on settlement of the subordinated person conflict of interest. At the same time, the current legislation defines the ways of conflict settlement (external and independent) and does not detail the forms of such settlement (oral or written), its specificity, which directly depends on the type of conflict of interest, the form of its notification, time of occurrence, etc. All this requires a detailed research of ways of conflict of interest settlement in public-law relations.

Analysis of recent research and publications. Among the works devoted to separate aspects of the problem of conflict of interest, we can distinguish such authors as T. Vasilevskaya, V. Galunko, N. Korchak, V. Lugovoy, D. Lukianets,
A. Mikhalchenko, S. Rivchachenko, V. Senik and others. Such scientists as V. Aleksandrov, V. Kolpakov, M. Melnik, S. Rogulsky, S. Stetsenko, V. Tilchik, A. Tkachenko, G. Tuchak, I. Yatskiv. At the same time, the conflict of interest settlement has not been studied in a comprehensive manner.

The purpose of the article is to identify the problems of legal regulation of the conflict of interest settlement in public-law relations, to determine specific proposals for their solution.

Presentation of the main material. In accordance with Clause 1. Art. 28 of the Law of Ukraine "On Prevention of Corruption" [1] to public administration entities (in particular, persons authorized to perform functions of the state or local self-government, and persons equal to them) are subject to the requirements, first, to take measures to prevent the emergence of a conflict of interest, secondly, to inform the supervisor or other person in the way prescribed by law about 
the potential or real conflicts of interests, and, thirdly, not to take actions and not make any decisions until measures for settlement the conflict are taken. How to settle the conflict is stated in Art. 29 of the Law - these are measures of external and non-dependent settlement. From their content, it follows that a conflict of interest can be settled in two ways, firstly, independently, by a person who has a conflict of interest without the involvement of officials, and secondly, by external influence from other authorized persons (its directors, the NSC, other bodies and officials designated by law). The measures of external conflict of interest settlement are defined: 1) removal of a person from performing a task, committing an action, taking a decision or taking part in its adoption in the conditions of a real or potential conflict of interests; 2 ) the use of external control over the execution of a particular task by a person, the commission of certain actions or decision-making; 3 ) restriction of access of a person to certain information; 4) review of the scope of official authority of the person; 5) transfer of person to another post; 6) dismissal of a person. Specific measures for the self-settlement of a conflict of interests do not include the article under consideration, but it is indicated that the result of their application should be the deprivation of the relevant private interest of the person who became one of the causes of the conflict.

Depending on the type of legislative regulation of ways to settle conflicts of interest, they can be divided into: a) general (stipulated by the Law of Ukraine "On the Prevention of Corruption" [1]); b) special (they have their own specifics, are determined by the laws regulating the status of individuals and the principles of organization of the relevant bodies, for example, the head of state, people's deputies, members of the government, heads of central executive bodies, judges, chairmen of local councils, their deputies, etc.). Given this, the list of measures for the external and independent settlement of conflicts of interest envisaged by Article 29 of the Law is not exhaustive and may vary depending on the peculiarities of the service, the employment of the persons concerned, and the specifics of the organization of the activities of the relevant bodies, enterprises of the institutions and organizations. The above list of measures for the external conflict of interest settlement is also not a certain sequence of their application or choice. The choice of a specific measure depends on a number of factors: the type of conflict (potential or real), its duration (temporary or permanent), the subject, which it emerged (officials of state bodies, local selfgovernment, employees of other legal entities of public law, persons providing public services, etc.), subjects authorized for its settlement (heads of state bodies, bodies of local selfgovernment, state and communal enterprises, institutions, organizations of their divisions, collegial bodies directly or with the participation of the representative or the NACC body, public associations), the presence (absence) of the consent of the person to apply for a particular measure, the form of settlement (oral or written), etc. Let's consider them in more detail.

Despite the fact that the rules of Part 1 of Art. 29 of the Law does not specify the kind of conflict of interest to which external measures will be applied (although they are mentioned in the following articles of the Law), it should be emphasized that the purpose of their application the settlement - can be reached on a potential conflict with the absence of the influence of private interest in the objectivity or impartiality of decisionmaking, or in the commission or non-execution of duties during the performance of official authority. Otherwise, there is a violation of conflict of interest law, and the settlement measures will be aimed at preventing the emergence of potential or real conflicts of interest in the future.

Conflicts of temporary (one-time) nature are regulated by such a measure as eliminating a person from performing a task, committing an action, taking a decision or taking part in its adoption in a conflict of interest (Article 1, part 1, Article 29 of the Law). Those conflicts that have a permanent nature are settled by other measures envisaged in paragraphs 3-6 of Part 1 of Art. 29 of the Law. Conflicts of both temporary and permanent nature can be settled by an external control over the performing of a particular duty by a person (clause 2, part 1, Article 29).

Specificity of the subject, who has a conflict of interest, causes the choice of the authorized person action to settle it. Such measures as the transfer of a person to another position, as well as his dismissal, shall be applied only by the head of the body, enterprise, institution or organization. The decision on the application of other measures of external regulation may also be taken by the direct supervisor of the person.

The decision to remove a person from performing a task, committing an action, taking a decision or participating in its adoption in a real or potential conflict of interest may be taken both 
verbally and in writing. Decisions on the application of other measures of external settlement are taken in writing.

The election of a measure of an external conflict resolution of interests should be carried out objectively, taking into account the interests of the person in which it arose, the specifics of its official powers, in order to prevent violations of rights, freedoms and legitimate interests of individuals and legal entities. In any case, the election of a measure should be sufficient to settle the conflict of interests (that is, streamlining the activities of the persons concerned) and, at the same time, minimally possible interference with the performance of their official or representative powers [2, p. 122]. An external conflict of interest settlement is the area of responsibility of the manager, other authorized person or body, the level of which allows and obliges to take measures to settle the conflict of interest. Violation of legislation should recognize supervisor's decisions, instructions to the person about the need for an independent settlement of the conflict if it provides the application of measures of external regulation.

Part 2 of Art. 29 of the Law sets a requirements for the independent settlement of a conflict of interests: 1) a person settles a real or potential conflict of interests; 2) measures to settle the conflict are committed by a person who has a conflict; 3) a person who has a conflict can solve it independently; 4) the settlement is carried out by depriving the relevant private interest; 5 ) deprivation of private interests shall exclude any possibility of its concealment: 6) providing the direct supervisor with confirming documents for deprivation of the relevant private interest. Despite the fact that the concrete measures of such a way of settlement are not defined by law, their example is the transfer from official to another person management the enterprise and corporate rights in the manner prescribed by law (Article 36 of the Law).

Let's consider more specifically the measures of external conflict of interest settlement. The removal from the performance of a task, commission, decision-making or participation in its adoption consists in the transfer of authority to make a decision or to act from another person in conflict. It is used in the aggregate of the following conditions:: 1) to a real or potential conflict of interest; 2) the conflict of interests is exclusively temporary; 3 ) applied by the decision of the head of the relevant body, enterprise, institution, organization or head of the relevant structural unit in which the person works; 4) there is the possibility of engaging in the decision or action that created the conflict situation, another employee of the appropriate body, enterprise, institution or organization, regarding the fourth condition, it should be noted that the list of such persons should be expanded in the Law with the decision-maker person (supervisor), who can settle the conflict by making a decision or performing conflicting actions by himself. The supervisor's decision can be taken both verbally and in writing. The choice of the appropriate form depends on how the employee was assigned duties that caused a conflict of interest. If the conflict arose as a result of the receipt of oral instructions from the head or the current performance of official authority, the decision to remove and engage another employee may be taken orally, of course, it does not preclude the use of written form. In cases where the conflict was reported to the head of the writing, the performing of the authority is entrusted to the employee by an administrative act (for example, an order to carry out an audit of the enterprise, inclusion in the certification committee, other written order, etc.), then the decision of the relevant head of the considered an external settlement should be taken in writing.

Restrictions on access to information as an external conflict resolution measure have many features in common with the previous one - it is used in the event of a potential or real conflict of interest, upon the decision of the head of the relevant body or the head of the relevant structural unit in which the person works, there is the possibility of engaging in work with the corresponding information that creates a conflict situation for another employee. Distinctive features are, firstly, the type of conflict (only a long-term, permanent nature, in cases where the conflict has a one-time character, it is necessary to apply such a measure as the removal from the execution of the assignment, the commission of actions), and, secondly, there is the possibility of continuing the duty performance by the person whose access to information was limited. The law does not establish the type of such information. According to Art. 1 of the Law of Ukraine "On Information" [3], information is any information and / or data that can be stored on physical media or displayed in electronic form. Therefore, the restriction of access is applied to the information, not the document that contains it. 
In our case, it is the information with the limited access. Even if a person at the time of performing his duties has an access to certain information by using an official digital signature or key, but such information may be obtained from open registers or databases (for example, the Unified State Register of Legal Entities, individuals-entrepreneurs and public formations, the Electronic System for Disclosure of Stock Market Participants, etc.), the restriction of access to such information does not settle the conflict of interest. Access should be restricted to the official information contained in documents, internal correspondence, memos related to the performance of supervisory powers, decision-making, or collected in the course of investigative activities or other activities that are not assigned to state secrets. In this case, the work of a person must be permanently connected with access to a particular type of information that is the sphere of his private interest.

Therefore, the decision of the manager to restrict the access of a person to certain information should include: a justification for the application of this measure; a specific list of restricted access information and an indication of the means by which it will be implemented (for example, the removal of an electronic key); limitation period (until the conflict of interest loses relevance); data about the person entrusted with work with the relevant information. It means that the decision should be made in writing.

The goal of the scope of authority review is to exclude (replace to others) from the employee functional duties the powers - reasons of a conflict of interest. It can be applied only with a whole set of the following conditions: 1) when the conflict of interest is real or potential; 2 ) if the conflict of interest is permanent and is related to the specific powers of the person; 3) applied by the decision of the head of the body, enterprise, institution, organization or corresponding structural unit in which the person works; 4) review of the duties does not exclude the possibility of continuing the performing other powers of the person; 5 ) other officials of the body, enterprises, institutions and organizations may be assigned powers that were excluded from the person. This measure of external control should be distinguished from: limiting access to information (Article 31 of the Law), transferring a person to another post (Article 34 of the Law); changing essential conditions of civil service (Article 43 of the Law "On Civil Service"); transfer to another job, change essential conditions of work (Article 32 of the Labor Code). The decision to review the scope of the authority of the person is taken in writing.
Transfer, dismissal of a person due to the existence of a conflict of interest. The common features of these external conflict resolution measures are: they are applied to a real or potential conflict of interest with a permanent nature; decision-maker is the head of the body, enterprise, institution or organization. The decision to transfer a person to the other position is taken in cases where other measures of conflict settlement cannot be applied, while the other position is free and corresponds to the personal and professional qualities of the person. As we see, the Law does not specify what type of post the person should be transferred to. The answer to this question is contained in the legislation that determines the particularity of a certain type of service or employment. Thus, persons whose work is regulated by the Law of Ukraine "On Civil Service" [4] may be transferred without compulsory holding of the contest for another equivalent or lower vacancy in the same or another state body, including in another location. The post of civil service belonging to one group of remuneration, taking into account the jurisdiction of the state body, is equally recognized. Accordingly, a lower position should be considered a post belonging to the lower wage group, as well as a post with a lower level of jurisdiction, albeit within the same group of remuneration. If a civil servant was appointed to a position without a contest, he cannot be transferred to a higher post without a contest.

The law also states that the transfer of a person to another post can only take place with his consent.

Dismissal from the position of the person who caused the conflict of interest is the most severe measure of the external conflict of interest settlement, which, in addition to the above general conditions, applies when the conflict cannot be settled in any other way, including because of the lack of consent of the person to the transfer for another post, the absence of such posts or the reluctance to get rid of the private interest that has become the cause of the conflict.

The transfer and dismissal of a person are most often used in cases where the conflict of interest relates to direct subordination relations between close relatives or other persons related to private interest.

As with previous measures for conflicts of interest settlement, the form of the decision is not defined by law. Of course, it should be written.

Performing duties under external control is a special measure of external conflict of interest 
settlement. This feature is based on the fact that the employee, despite his private interest, makes a decision and acts in a potential conflict of interest, but by the decision of the head in the form of control he has defined. The main purpose of this measure is to exclude the influence of a person's private interest on the objectivity or impartiality of decision-making, or taking action. It is applied in the aggregate of the following conditions: 1) when the conflict of interest is real or potential; 2) the conflict of interests has a temporary character, and in certain cases it can be permanent; 3 ) it is impossible to apply such measures to settle the conflict of interests as removal of a person from performing a task, restriction of access to information and reviewing his / her official authority; 4 ) there are no reasons for the transfer of a person to another post or for his dismissal.

Article 33 of the Law does not specify who is authorized to decide on the use of external control. Therefore, it can be decided by the head of the body, enterprise, institution, organization, and the head of the relevant structural unit in which the person works. Proceeding from the content of this measure and requirements for its formalization, it is advisable to make such decision by the supervisor of the level not lower than the head of an independent structural unit, in which the person works.

The choice of a specific form of external control, as defined by the Law, is carried out taking into account the peculiarities of the conflict of interests that arose, the decision and / or action to be taken, the competence of the persons involved in the control, the requirements for the quality of the performing work, the employee work experience, etc.

Thus, the checking of the condition and results of the person task performing, the commission of its actions, the content of decisions or draft decisions, adopted or developed by him or the relevant collegiate body on issues related to the subject of conflict of interest, by another employee, chosen by supervisor, consists in the following (retrospective) control of decisions or actions taken by the person, who reported about conflict of interests, on the subject of their objectivity, legality, compliance with other requirements. This form of control can also be applied to check the activities of a collegial body, except when a non-participation of a person who has a conflict of interest would lead to the loss of the authority of such a body.

Such a form of control as the performing the task, actions, the consideration of cases, preparation and adoption of decisions by a person in the presence of the employee appointed by supervisor consists in current (operational) controlling, direct observation of the actions and decisions taken in "real-time" (in tandem with designated employee) for the purpose of prompt detection and timely termination of violations that may arise as a result of the influence of private interest on actions and decisions objectivity or impartiality.

The last form of external control is the participation of the authorized person of the National Agency for the Prevention of Corruption in the work of the collegial body in the status of an observer without the right to vote. It applies in cases where the nonparticipation of the person (who reported about conflict and is a member of the collegial body) in decision making by this body will lead to the loss of its authority. The decision to apply this form is taken by the relevant collegiate body. The decision defines only the form of external control, which is reported to the National Agency for the Prevention of Corruption, that identifies an authorized person to participate in the work of the collegial body as an observer. Although the participation of such a person in the voting is excluded, during the work of the collegial body it may be found violations of legislation in the field of prevention and counteraction to corruption.

The legislator has defined the main requirements for the content of the decision on the implementation of external control. It defines the specific form of control authorized to carry out the control of the employee, as well as the responsibilities of the person in connection with the use of external control over the performance of the task, the commission of its actions or decision-making. Taking into account this, the most optimal form of the decision taken by the head of the decision on the use of external control should be written regulations, which has a certain procedure of preparation and registration.

Conclusion. Despite the broad legal framework and the interpretation of external and non-dependent conflict of interest settlement, there are practical problems with their application, due to gaps in detailing such measures, determining the forms of managerial decisions, requirements for the organizational level of such a supervisor, etc. The decision to eliminate a person from performing a task, committing an act, taking a decision or taking part in its adoption in a real or potential conflict of interest 
should be foreseen in oral or written, for others - only written. For such type of settlement as a removal from the performing of a task, action, decision-making or participation in its adoption, it should be foreseen that a leader, regardless of the presence / absence of another employee, should personally make decisions or perform actions that underlie the conflict. It is advisable to foresee that the decision to perform powers under external control has to make a leader of the level not lower than the head of an independent structural unit, in which the person works.

\section{References:}

1. Про запобігання корупції : Закон України від 14.10.2014 р. № 1700-VII. Відомості Верховної Ради. 2014. № 49. Ст. 2056.

2. Науково-практичний коментар до Закону України «Про запобігання корупції» / Наук. ред. Хавронюк М.І. Київ : Ваіте, 2018. 472 с.

3. Про інформацію : Закон України від 2 жовтня 1992 р. № 2658-XI. Відомості Верховної Ради України. 1992. № 48. Ст. 650.

4. Про державну службу : Закон України від 10 грудня 2015 р. № 889-VIII. Відомості Верховної Ради. 2016. № 4. Ст. 43.

\section{Пастух І. Д. Врегулювання конфліктів інтересів на публічній службі}

У науковій публікації на основі чинного законодавства, досягнень юридичної науки розкриваються актуальні проблеми врегулювання конфрліктів інтересів у публічно-правових відносинах. Констатується, що чинне антикорупційне законодавство неповною мірою визначає форми та прочедури врегулювання таких конфрліктів, що безпосередньо залежить від їх специфріки, тривалості, змісту конфрліктної ситуації тощо. Все це призводить до складнощів врегулювання конфрліктів із боку уповноважених суб'єктів.

Розкрито підходи законодавця щодо шляхів врегулювання конфллікту інтересів у діяльності публічної адміністрації. Роз'яснено порядок та підстави використання заходів самостійного та зовнішнього врегулювання конфлікту інтересів. Зазначається, що обрання конкретного заходу щодо врегулювання зовнішнього конфлікту інтересів має здійснюватися об'єктивно, враховуючи інтереси особи, яка має конфрлікт, специфріку своїх службових повноважень, щоб запобігти порушенням прав, свобод та законних інтересів фрізичних та юридичних осіб.

Детально описані способи застосування заходів зовнішнього врегулювання конфрлікту інтересів з урахуванням типу конфрлікту, його тривалості, особи, в якої виник конфрлікт, особи, вповноваженої його врегулювати, форми врегулювання. Зокрема, зазначається, що рішення про усунення особи від виконання завдання, вчинення дій, прийняття рішення чи участі в його прийнятті в умовах реального чи потенційного конфрлікту інтересів може бути прийнято як в усній, так і письмовій формі. Рішення про застосування інших заходів зовнішнього врегулювання слід приймати лише письмово. Такі заходи, як переведення особи на іншу посаду, а також їі звільнення, застосовуються тільки керівником органу, підприємства, установи, організації. Рішення про застосування інших заходів зовнішнього врегулювання може бути прийнято безпосереднім керівником або керівником відповідного органу, підприємства, установи, організації.

Звертається увага на прогалини у відповідному законодавстві, конкретні пропозиції щодо їх усунення визначаються шляхом законодавчого закріплення фрорми рішення керівника щодо врегулювання конфлікту, вимог щодо його організаційного рівня.

Ключові слова: конфрлікт інтересів, публічна адміністрація, потенційний конфрлікт інтересів, реальний конфрлікт інтересів, заходи зовнішнього врегулювання, самостійні заходи врегулювання. 